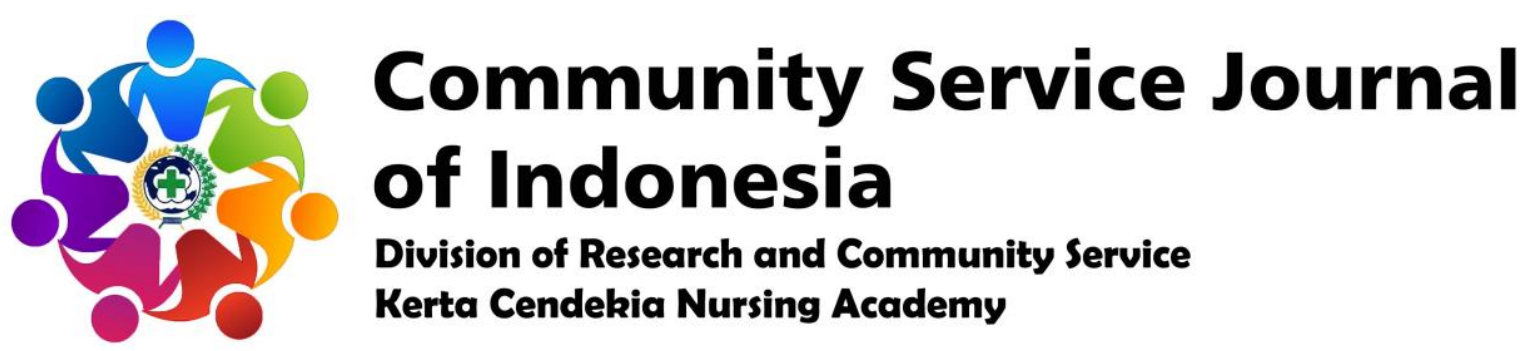

https://ejournal-kertacendekia.id/index.php/csji/index

Community Service Journal of Indonesia 1 (2) (2019): 25-27

Doi: https://doi.org/10.36720/csji.v1i2.134

\title{
IMPROVING ADOLESCENT KNOWLEDGE OF SMOKING HAZARDS
}

\author{
Meli Diana ${ }^{1}$, Sulfatus Zakiya ${ }^{2}$, Intan Nurul Anggriani ${ }^{2}$, Dince Debora Saikmata ${ }^{2}$, \\ Retno Dwi Puspita Sari ${ }^{2}$, Fitria Isnaini Ramadhani ${ }^{2}$, Jannatun Noer Khabibah ${ }^{2}$, \\ Khaidar Rachman ${ }^{2}$, Tri Astutik Wahyu Utami ${ }^{2}$ \\ ${ }^{1}$ Lecturer of Kerta Cendekia Nursing Academy, Sidoarjo \\ ${ }^{2}$ Student of Kerta Cendekia Nursing Academy, Sidoarjo
}

\begin{abstract}
Health Promotion Activities about the Dangers of Smoking in Adolescents at MTs Islamiyah Tanggulangin, Sidoarjo is one form of community service in the form of counseling aimed at growing and improving healthy behavior in adolescents, especially in recognizing the dangers of smoking for health. The activity was carried out on November 21, 2018 at MTs Islamiyah Tanggulangin, Sidoarjo. The target is students of MTs Islamiyah Tanggulangin Sidoarjo. Before the activity is carried out, there is a process of compiling the activity for 3 weeks before the activity is carried out, starting from the selection of health counseling materials to the submission of permits to the relevant parties. As an evaluation, the activity was attended by 40 students and 2 teachers, participants participated in the activity with enthusiasm and conducive, the activity can be carried out on time smoothly.
\end{abstract}

Keywords: Adolescent knowledge, smoking hazard, health promotion.

\section{INTRODUCTION}

Teenagers are the successor to the nation's generation. However, teenagers now often underestimate their health. They only think of what will make them happy, like cigarettes. The more teenagers use cigarettes at a young age without regard to the consequences that will result from these behaviors.
Because this can have a negative impact on his health, his school and others. Usually this is done by students because their unstable emotional conditions make them do everything to vent their emotional. The smoking population at an early age is very high. This is because it will be due to lack of counseling about the dangers of smoking in schools or the community, or 
maybe also a lack of awareness of themselves so that they do not pay attention to the dangers and also going forward.

Smoking habits in Indonesia are very alarming. Not only dangerous for smokers, cigarette smoke is also very dangerous if inhaled by people around them (passive smokers). The health effects of smoking are a problem that occurs globally. The World Health Organization (WHO) estimates that there are more than 7 million deaths due to diseases caused by cigarette smoke every year. Around 890,000 cases of death occur in passive smokers around the world.

We realize that information about the danger of smoking for health is very important to be known by the wider community, especially students. This is what prompted us to compile this proposal about the Dangers of Smoking Among Teenagers. We hope that by knowing this information students can discourage them from consuming cigarettes, or even stop smoking.

\section{OBJECTIVES}

General Purpose

After doing health promotion, it is expected that all students of MTs Islamiyah Tanggulangin, Sidoarjo will be able to understand even more about the Dangers of Smoking.

\section{Special Purpose}

After taking action on health promotion, it is expected that the students of MTs ISLAMIYAH Tanggulangin, Sidoarjo can be:

1. Able to identify dangerously in cigarettes.

2. Able to identify diseases caused by smoking.

3. Able to identify complications from the dangers of diseases caused by smoking.

\section{PLAN OF ACTION}

Strategy Plan

The strategy plan implemented, including:

1. Coordinate with the principal of MTs Islamiyah Tanggulangin, Sidoarjo to request permission to carry out health education or counseling as an activity of the nursing program and to help give direction to students of MTs Islamiyah Tanggulangin, Sidoarjo.

2. Set targets on students in the implementation of health education or counseling with the aim of knowing about the Dangers of Smoking.

3. Conducted a time contract for implementing health promotion with students of MTs Islamiyah Tanggulangin, Sidoarjo.

4. Provide counseling about the dangers of smoking.

\section{Implementation}

Actions taken in the implementation of these activities, including:

1. Contacted the principal of MTs Islamiyah Tanggulangin, Sidoarjo to get an activity permit and gathered students at MTs Islamiyah Tanggulangin, Sidoarjo.

2. Prepare a place and counseling media.

3. The students of MTs Islamiyah Tanggulangin, Sidoarjo received counseling material.

\section{Setting}

This activity was carried out at MTs Islamiyah Tanggulangin, Sidoarjo.

Target

Target in this activity is all students at MTs Islamiyah Tanggulangin, Sidoarjo. 


\section{RESULTS AND DISCUSSION}

The activity was carried out on November 21, 2018 at 09.45 West Indonesia Time in the classroom of MTs Islamiyah Tanggulangin, Sidoarjo. The implementation schedule is in accordance with the schedule that was mutually agreed between the executor of the health promotion activity and the school.

Participants in the counseling of 40 students at MTs Islamiyah Tanggulangin, Sidoarjo. Equipment used during the discussion were laptops, powerpoints, videos, and leaflets. The use of language is very communicative and applicable in the delivery of health education, students respond fairly well to what has been delivered by the presenter. The teacher from MTs Islamiyah Tanggulangin, Sidoarjo was very enthusiastic and cooperated very well during the outreach. Participants who attended seemed enthusiastic about attending counseling from beginning to end. Questions asked by participants can be answered well by the presenter and the team.

Based on the results of the final evaluation carried out by the health promotion implementers it was found that $75 \%$ of participants could mention the meaning of cigarettes. $85 \%$ of participants can mention the content in cigarettes. $90 \%$ of participants can practice about the dangers of smoking and smoking cessation tips. $80 \%$ of participants can follow the counseling material well.

\section{CONCLUSION}

Improving adolescent knowledge of smoking hazards through health promotion was considered quite successful because almost all students were able to mention the definition of cigarettes $(75 \%)$, mentioning the content in cigarettes (85\%), mentioning the dangers of smoking and practice the smoking cessation tips (90\%), and able to follow the counseling material very well $(80 \%)$.

\section{REFERENCES}

Armstrong, Sue. (1991). Pengaruh Rokok Terhadap Kesehatan. Jakarta: Arcan Mandagi.

Jeanne. (1996). Masalah Narkotika dan Zat Adiktif Lainnya serta Penang gulangannya. Jakarta: Bina Darma Pemuda Printing.

Smeltzer, S.C., \& Bare, B.G. (2002). Buku Ajar Keperawatan Medikal Bedah Brunner \& Suddarth, Edisi 8 vol 2. Jakarta: EGC.

Mansjoer, A. (2004). Kapita Selekta Kedokteran, Edisi Ketiga, jilid satu. Jakarta: Media Aeskulapius. 